\title{
Proceeding
}

Supplementary Issue: Autumn Conferences of Sports Science. Costa Blanca Sports Science Events, 2-3 November 2018.

Alicante, Spain

\section{An innovative Educational-Sport strategy to aim to inclusion: Biodanza SRT}

\author{
DOMENICO TAFURI 4 , ROBERTA ROSA, DAVIDE DI PALMA, ANTONIO ASCIONE \\ University Parthenope of Naples, Italy
}

\begin{abstract}
In the perspective of inclusive didactics, the differences are not only accepted, but also stimulated, valued, used in daily activities to work together and grow both as individuals and as a group. The basis of this new vision of the teaching-learning approach is precisely the "motor activities and the corporeity which, starting from what a person is able to give or to do, stimulate the consideration of oneself and one's own existence. In this regard, the aim of this paper is to identify and analyse the Biodanza SRT System as an educational strategy that, within the Inclusive Didactics-related teaching-learning process, represents a new innovative methodology able to contribute to the enhancement of diversity as a resource, and bring benefits to the overall well-being of the disabled or discomfort person, by facilitating a better "functioning" of the social context he is included (ICF-CY) and favouring Well-being and Inclusion. Through a careful analysis of literature references and protocols already exist for this educational-sport strategy arrive at a result that Biodanza is not considered as a therapy as it does not act on symptoms, conflicts, and disorders, but, in a therapeutic way, it stimulates the "healthy part" and its inclusion in programs or protocols: it is not intended as an "alternative" proposal but as a further strategy to be integrated with the actions already implemented in the different contexts. From the point of view of Special Didactics, the Biodanza seems to be an excellent strategy to aim to inclusion and "normal specialty". Key words: Biodanza SRT; Special Educational Needs; SEN; Inclusion; Inclusive didactics.
\end{abstract}

\section{Cite this article as:}

Tafuri, D., Rosa, R., Di Palma, D., \& Ascione, A. (2019). An innovative Educational-Sport strategy to aim to inclusion: Biodanza SRT. Journal of Human Sport and Exercise, 14(1proc), S1-S10. doi:https://doi.org/10.14198/jhse.2019.14.Proc1.01

Corresponding author. Department of Motor Science and Wellbeing, University Parthenope of Naples, Naples, Italy.

E-mail: domencio.tafuri@uniparthenope.it

Supplementary Issue: Autumn Conferences of Sports Science. Costa Blanca Sports Science Events, 2-3 November 2018. Alicante, Spain.

JOURNAL OF HUMAN SPORT \& EXERCISE ISSN 1988-5202

(c) Faculty of Education. University of Alicante.

doi:10.14198/jhse.2019.14.Proc1.01 


\section{INTRODUCTION}

In the perspective of inclusive didactics, the differences are not only accepted, but also stimulated, valued, used in daily activities to work together and grow both as individuals and as a group (AA.VV., Erickson, 2015).

The basis of this new vision of the teaching-learning approach is precisely the "motor activities and the corporeity which, starting from what a person is able to give or to do, stimulate the consideration of oneself and one's own existence" (Gianfragna, 2005).

Starting from this dimension, in an inclusive school, Motor Sciences represent the "selected space" in which to experiment oneself, and at the same time become the "privileged means" through which to develop the subject's identity, self-efficacy (Bandura, 1996/2000), self-esteem, personal autonomy, and ecological relationships, favouring the development of every individual's personal, social, interpersonal, cognitive and affective psychosocial skills.

As part of the teaching-learning process, new innovative methods capable of improving health, well-being and inclusion, are increasingly used and simultaneously taken into analysis for continuous research. In recent years, the "Biodanza SRT" system has been introduced in different educational and/or rehabilitation contexts, arousing considerable interest also in experimentation and research activities aimed at investigating its effectiveness, and its ability to offer an educational value that strengthens identity, enhances talent and diversity as a resource, dialogue and exchange, restoring quality to human relationships.

Putting inclusion at the centre of educational policies and educational practices means focusing attention on the diversified needs of all students, excluding no one, respecting the principle of equal opportunities and active participation that everyone holds.

\section{METHOD}

\section{Analysis of Literature References and Biodanza Protocols} Inclusion and Inclusive Didactics

The world of school has to deal more and more often with SEN students: people who, despite not having a medical or psychological diagnosis, find themselves in difficulty and need an individualized didactic action.

Special educational needs can have different origins: organic, family and environmental difficulties, social and cultural differences, causing people instability, barriers or delays in learning processes.

Inclusive didactics aims at making the school context inclusive through the different dimensions of teachers' actions, didactics, assessment and school organization, providing the benefit of enhancing diversities by considering them as real "resources".

If integration aims at searching for what does not work in the individual, and at identifying specific solutions, inclusion is a process based on everyone's active participation in school life, by identifying and removing barriers that may hamper learning. Therefore, the inclusive school becomes the place in which to respond to the needs of everyone.

Inclusion must start from special normality, that is, from the need to feel like everyone else and the need to be considered in relation to one's own characteristics. 
In the perspective of an inclusive Didactics, therefore "There can be four lines of action (lanes, 2001):

1. On Teachers' Professionalism;

2. On the Class Climate;

3. On the Learning Modalities;

4. On the Contents And Tools "(Miato, Miato 2003).

The teacher assumes a facilitating role when taking care of the student in his totality, and a strategic role in the promotion of a good class climate.

"The class group is an educational and didactic resource where everyone can gain energy and support to dedicate himself to his own self-realization: it is a place in which to build, together with others, one's own cognitive map and personality. By cultivating well-being, welcome, solidarity and responsibility in the classroom, the formative process becomes more pleasant and effective "(Polito, 2000).

From this it follows that "a more inclusive school climate allows everyone to feel accepted, understood and valued; it develops the sense of belonging, of positive interdependence and empowerment; it contributes to creating a solid socio-affective ("I feel loved, respected, considered"), communicative ("Everyone listens carefully to what I say and they really care about my point of view") and relational basis ("Our class makes me feel fine, there is friendship, mutual help, solidarity and the someone's problem becomes everyone's problem »)" (Miato, Miato, 2003).

Inclusive didactics is everyone's didactics, aimed at personalizing and individualizing the interventions through active, participatory, constructive and affective methodologies.

An inclusive methodology is represented by cooperative learning that, in Johonson and Johnson (1987), is defined as "a teaching methodology with social mediation, which involves the intentional use of small groups working together to maximize their mutual performance" (Johnson \& Johnson, 1987).

This teaching strategy can create an inclusive environment, because, as lanes and Cramerotti state, "... the principle is that each member of a group, with his peculiar and special characteristics, can contribute to everyone's learning and everyone can become a resource (and a compensatory tool) for the others" (lanes, Cramerotti, 2013).

"We need - therefore - to work together with others, in view of common objectives, especially to:

- $\quad$ Raise the level of all students, even those with special educational needs or disabilities;

- Build positive relationships among students, in order to create a learning community in which diversity is respected and appreciated;

- $\quad$ Provide students with the experiences they need for a healthy cognitive, psychological and social development (lanes, Cramerotti, Capaldi, Rondanini, 2016).

It is also necessary that students learn to be aware of what they do. In metacognitive didactics, the teacher must focus on developing the student's knowledge of his own mental processes, by contributing to the construction of his own identity, personal autonomy and skills. 
As highlighted by Chiari (1994) "There are categories in team work that are traditionally absent in the teachercentred didactic process: participation (of the student in his own learning process), responsibility (in relation to the student's work and that of his classmates too), reflection (on the sense of one's own action holding a meaning, and on one's own role as a student), sharing (of one's own ideas, information, materials, and data), and taking care of others (caring). These categories tend to be strengthened in the didactic models based on the structured work group and on the team, in which both the work productivity, the identity and the selfesteem of the participating students, and finally the altruism and the sense of the other and of the different, are strengthened.

The inclusive school is therefore a way of doing school in which it is essential to improve everyone's health and well-being condition, the achievement of autonomy and the awareness of belonging to a learning community (Canevaro, 2013).

Ghedin (2017) emphasizes that "well-being is defined as the realization of one's own physical, emotional, mental, social and spiritual potential, inspired by a harmonious commitment in tune with oneself, family and friends, the community and the world in general.

With the term well-being, the ICF intends to indicate "the whole universe of the domains of human life, including physical, mental and social aspects, which constitute what can be called a good life" (WHO, 2007), expanding the focus also to education (Ghedin, 2014), environment, work (Canevaro, 2006), and sport (Visentin, 2016); areas which have never ever been contemplated in previous models with a biomedical approach before.

The ICF deals with people's lives. From this point of view, disability should be considered as one of the many possible health states understood not only in the general sense of the term, but it needs to expand its meaning by also evaluating the involvement of the most useful type of approach for social and personal integration.

\section{The "Biodanza SRT" (Rolando Toro's System) as an inclusive proposal}

"Biodanza SRT" (Rolando Toro system) is an experiential ideal-affective-motor system (Toro Araneda, 2007) that through the experience of the body, emotion and encounter, re-establishes the balance between "feeling, thinking, and acting ".

Biodanza was founded in 1960 and stems from Rolando Toro Araneda's personal experience and research; the Chilean psychologist and anthropologist drew on the foundations of Biology, Anthropology, Psychology, Sociology, Neurophysiology and the most recent research of Neuroscience and Human Sciences. Through research carried out on healthy and mentally ill participants at the Center for Medical Anthropology of the University of Chile's medical school, the discipline became the subject of a university course in 1970 within the Department of Aesthetics of the Pontifical Catholic University of Chile, where Prof. Toro was appointed to the chair of "Psychology of Expression".

The term Biodanza comes from the Greek prefix Bios, which means "Life", and the French word Danse, meaning an "Integrated emotional movement", and its translation is: "The Dance of Life".

The innovative methodology of "Biodanza SRT", through specific exercises generated by the interaction between music (universal language), movement/dance (natural expression of the human being), emotion (existential sensitivity) and vivencia (the moment lived with intensity "here and now"), is based on the experience lived in a group (as a strengthened of identity and sense of belonging), a place of human 
encounters, where everyone's diversities are recognized, valued and accepted in the broadest feeling of belonging to Humanity.

Through specific exercises generated by the interaction between music, movement/dance, emotion (existential sensitivity) and vivencia, Biodanza facilitates:

- $\quad$ Human integration (with oneself, the other and the context);

- $\quad$ Organic renewal (Stimulation of homeostasis and reduction of stress factors);

- $\quad$ Affective re-education (a founding nucleus of the identity and a bond with the species);

- $\quad$ Re-learning the original life functions (awareness of healthy instincts; natural responses that arise spontaneously in each individual).

In Biodanza, realizing "one's own dance" does not mean emulating a movement to perfection or learning preestablished movement codes; realizing one's own dance means integrating one's own feelings with one's own actions, creating a communion between feelings and emotions that animate us and their visible expression of our way to move into the world.

The "Biodanza SRT" methodology pursues the aim of promoting the harmonious and integrated development of human potentialities (Lines of Vivencia), which are key to contributing to the structuring the person's identity:

$\checkmark \quad$ Vitality (the ability to live with joy of life and vitality, linked to the first experiences of movement, the feeling of energy and vitality);

$\checkmark \quad$ Sexuality (the ability to experience pleasure in living life, linked to the care and the type of physical contact received);

$\checkmark \quad$ Creativity (the ability to self-regenerate every day by creating one's own existence according to the degree of freedom in exploring the world, and it expresses itself in the ability to explore one's own life);

$\checkmark \quad$ Affectivity (the ability to create a contact and to be in a human relationship with affectivity, related to the sense of security and nurture conveyed by those who looked after us);

$\checkmark \quad$ Transcendence (the ability to live the relationship with everything that is outside of us, with the other, the world, the existence and life, by feeling part of the Universe; it depends on having felt sensations of harmony existential and joyful participation of the surrounding environment).

During their lives, people develop these fundamental functions in a natural way. Many people, however, strengthen some at the expense of others. Biodanza works by stimulating all five vital functions, especially those less developed, and then integrate and harmonize them becoming an opportunity for pleasant, progressive and secure personal growth, for those who want to get in touch with their real identity: "That intimate and moving feeling of being alive".

The Biodanza group function is essential that to realize a process of personal and social change, since it induces new forms of communication and emotional bond. The group is a matrix of rebirth in which each participant finds the affective and permissive control of his own change. The presence of the "similar" changes the person's functioning at all his levels, both organic and existential (2012).

Some research (Stuek e Villegas, 2012) proved the effectiveness of Biodanza on the regulation of one's own behaviour, on the stress management, on the promotion of a certain degree of serenity, optimism, autonomy, 
on the mastery of the environment in which a person finds himself, on the adoption of autonomous actions and on the establishment of positive relationships with others (Stueck, 2004; 2011).

From the outcomes of the research "Efficacia sulla salute di un corso annuale di Biodanza: uno studio empirico con 235 persone" ("Efficacy on the health of an annual Biodanza course: an empirical study on 235 people"), led by the Research and Intervention Psychologists Association - "Sapienza" University of Rome School of Specialization in Psychology of Health, and published in the journal Psicologia della salute (Giannelli, Giannino, Mingarelli, 2015), it can be observed that the Biodanza group members show, after about a year of training, an improvement in psychological well-being, a decrease in the stress levels and lower levels of alexithymia, while in the two control groups, Physical Activity and Sedentary Group, there are no significant variations showing that "Biodanza SRT" is effectively a practice of a person's health, well-being and development promotion.

During a Biodanza session a real empathic network" is developed, which constitutes, in all respects, a group intersubjective space within which there is a continuous exchange of experiences, an emotional resonance and a mutual recognition allowing the participants to be reflected in each other, to recognize themselves, to discover one another reciprocally, by strengthening one's own identity and restoring awareness of one's own transformation and change process (4). (Toro Acuna, Demelas, 2013).

Biodanza SRT is a system of personal growth and human evolution that awakens the attention to oneself, others and context, to sensitivity and empathy, so as to gradually increase self-confidence, self-esteem, selfefficacy, ability to listen and the strengthening of the identity, improving the well-being and the quality of personal and social life.

Through the "Learning by doing" approach, Biodanza offers the opportunity to learn and experience life through a fascinating journey into the discovery of one's own healthy side, in order to stimulate the process of personal renewal, positive self-assessment, self-esteem, and social integration by respecting human community and life.

The "Biodanza SRT" system is not considered as a therapy as it does not act on symptoms, conflicts or any disturbances, but it therapeutically stimulates the person's "healthy side" through dances/exercises, forming inductive models of Integrating Vivencias and that can therefore be proposed, with appropriate measures, also to people with motor disability and diversity.

From the study "Passi verso la felicità: il valore della Biodanza per promuovere l'inclusione" (Steps towards happiness: the value of Biodanza to promote inclusion"(Ghedin, 2016), experienced in the field of Mental Health, participants showed a greater ability to "perceive one's own individuality and, at the same time, one's own similarity with others, not perceiving themselves as "different" but as part of a group". Participants rediscover their uniqueness, and in this way they experience the joy of existing, which becomes contagious in this context, thus rediscovering the pleasure linked to the body, the ability to get excited and enter into a relationship with the other, with whom, during the dance, a meaningful emotional and empathic bond is established, so much so that we speak of Biodanza as poetics of the encounter (Ghedin2016).

A fundamental characteristic of the "Biodanza SRT" system is represented by its Universality, for it is an educational method with a heterogeneous and transversal application; in fact, it is suitable for men and women of all ages and is promoted in specific groups (children, adolescents, adults, elderly people, families, 
professionals, athletes, etc...) in educational, mental health, socio-health, rehabilitation, penal, and business contexts, and so on.

\section{RESULTS AND DISCUSSION}

\section{The innovation of the "Biodanza SRT" System}

"Biodanza is a system of acceleration of the integration/inclusion processes: it is existential, psychological, neurological, immunological and endocrinological (PNEI). Its practice is carefully based on the creation of an environment enriched with selected stimuli. Through music and exercises, the proposal can generate dynamic experiences that stimulate neuronal plasticity. Experiences stimulate the creation of new synaptic networks awakening a series of possibilities that previously had no form of expression. It is a highly integrative process that brings healing and preventive effects". According to this definition, it must be agreed that Biodanza ${ }^{\circledR}$ itself is an enriched environment: a space in which we welcome and are welcomed by the other, we stimulate and we are stimulated by the other, and where human relationships are at the basis.

"Biodanza is an Innovative Methodology and a highly refined System" (R.T.) that creates very concentrated fields of positive eco-factors (free/expressive emotional movement, affective communication, relationship with others, positivity, unconditional acceptance of diversity, non-judgment, active listening, contact, healthy emotions...) facilitating the learning and re-learning of affective communication, reparentalization and existential rehabilitation.

The "Biodanza SRT" System, through a person-centred approach in a facilitating and non-judgmental climate (with respect and attention to oneself and the other), induces people to establish "functional" interpersonal relationships, and to live their lives fully and creatively.

Positive vision (optimistic attitude), confidence in one's own possibilities (self-efficacy), active listening (effective communication), development of potentialities (self-esteem), empathy and emotional management are essential prerequisites for personal and collective growth and development. (Rogers, 1980).

The "Biodanza SRT" lab proposes an experiential/vivencial approach lived in a group with mainly practical and interactive settings. It offers a field in which to live verbal and non-verbal experiences in a non-judgmental and comparative relational space, within which every participant can measure himself against the other and, through the other, becomes aware of himself, in order to learn how to feel, explore, recognize and attach a name to his own emotions. The goal is to make it easier to get in touch with one's own moods and to avoid creating blocks, anxiety, aggression, in order to solve/relieve (or prevent) inner suffering, and reach a selfacceptance, a self-expression, by recovering relationships and providing a new opportunity for listening, personal and professional growth through the contact, and the re-owning of healthy emotions.

Relevant is also the aspect of emotional re-education that aims to fight against the condition of dryness and sterility of human relationships, where the possibility of establishing meaningful emotional bonds is often hampered by a destructive and violent society (Toro, 2013).

The "Biodanza SRT" system aims at promoting every individual's human value, and at representing, in this sense, an inclusive reality even for people who find themselves living in difficult situations. This intervention acts on all the human being's dimensions: that bodily, psychic, social and environmental, enhancing the Existential Rehabilitation as well-being and "quality life" promoter. "Biodanza SRT" thus becomes fully part 
of the new, increasingly widespread treatment perspective of the bio-psycho-social model and of Positive Psychology (Delle Fave \& Bassi, 2013 a, 2013b).

\section{CONCLUSIONS}

Just like Inclusive Didactics, Biodanza has the aim of facilitating the development of personal identity (regardless of any disability or discomfort), to the advantage of a better "functioning" of the social context in which a person is included (ICF-CY), in order to favour Well-being and Inclusion. "Biodanza SRT" sets itself as a valid inclusive tool able to support and contribute to the individual's personal growth, in order to promote global well-being by valuing its talents, by welcoming diversity as a resource in an inclusive context of "special normality "(lanes, 2006).

The inclusive environment cares to encourage everyone's participation, and Marisa Pavone (2010) attaches value to the individual, recognizes him in his own uniqueness, welcomes and envelops him, so that he can feel as totally belonging to community and making his own contribution to it, thanks to his talents and personal resources (Pavone, 2010).

"Biodanza SRT" can be understood as an inclusive and positive didactic strategy of this kind, since it is based on the belief that the participation of every single member of the group, set up to dance together, represents an enrichment for all the others (Ghedin, 2016).

By strengthening awareness of one's own identity, one's own and others' value and talent, fostering ecological communication, tolerance, dialogue with diversity, and cooperation, through the "Biodanza SRT" it is possible to promote positive attitudes and pro-social behaviours that develop an Eco-Logic and Bio-Ethic Vision, for it is able to lead the Human Beings to rediscover the pleasure of feeling protagonists, free and aware of their own life experience, in sharing and harmony with their peers and with the whole.

Biodanza fully responds to a methodological approach capable of triggering also a "Humanization process", which, through corporeality, favours the recovery of the empathic sensitivity.

The "Biodanza SRT" system is not considered as a therapy as it does not act on symptoms, conflicts, and disorders, but, in a therapeutic way, it stimulates the "healthy part" and its inclusion in programs or protocols: it is not intended as an "alternative" proposal but as a further strategy to be integrated with the actions already implemented in the different contexts.

From the point of view of Special Didactics, the "Biodanza SRT" System seems to be an excellent strategy for inclusion to not belong to the extraordinary anymore, and to become really a "normal specialty" (lanes, 2006).

\section{REFERENCES}

AA.VV. (2015). Bes a scuola, Erickson.

Bandura A. (1996/2000). II senso di autoefficacia, Trento, Erickson.

Canevaro A. (2006), Le logiche del confine e del sentiero. Una pedagogia dell'inclusione (per tutti, disabili inclusi), Erickson, Trento, pp. 81-90).

Canevaro A. (2013) Scuola inclusiva e mondo più giusto, Trento, Erickson. 
Chiari G. (1994). Climi di classe e apprendimento. Un progetto di sperimentazione per il miglioramento del clima di classe in quattro città italiane., Milano: Franco Angeli, 367 p. - (Collana di sociologia).

Delle Fave A., Bassi, M. (2013a) La psicologia e i modelli della salute. In: Psicologia e salute. Esperienze e risorse dei protagonisti della cura. Novara: De Agostini Scuola SpA, pp. 91-132.

Delle Fave A., Bassi, M. (2013b) La salute a tre dimensioni. In: Psicologia e salute. Esperienze e risorse dei protagonisti della cura. Novara: De Agostini Scuola SpA, pp. 3-39. 92.

Ghedin E. (2014). Conclusioni ICF e scuola: sfide e opportunità per promuovere l'educazione inclusiva. In F. Gomez Paloma (a cura di), ICF e scuola. Dalla Sinergia istituzionale al Progetto di vita (pp. 189207). Trento: Erickson.

Ghedin E. (2016). Passi verso la felicità: il valore della Biodanza per promuovere l'inclusione, in Journal of Special Education for Inclusion, anno IV-,2 Pensa Multimedia Editore, p. 204.

Ghedin E. (2017). II valore del ben-essere educativo. Una ricerca esplorativa sulle aspirazioni al benessere per studenti e docenti. Italian Journal of Special Education for Inclusion.

Gianfragna R. (2005). Lo sport come mediatore per la crescita della persona disabile, in L'integrazione scolastica e sociale, n. 6/4, 2007, p. 320. Cfr. anche L. de Anna, Progettare e promuovere Attività Motorie e Sportive Integrate nella formazione di persone con disabilità, in L'integrazione scolastica e sociale, n. 4/1, p. 39).

Giannelli M.T., Giannino P., Mingarelli A. (2015). Efficacia sulla salute di un corso annuale di Biodanza: uno studio empirico con 235 persone, in rivista Psicologia della Salute Fascicolo 1.

lanes D. (2001), Il bisogno di una "speciale normalità" per l'integrazione, "Difficoltà di apprendimento", vol. 7, n. 2, pp. 157-164.

lanes, D. (2006). La speciale normalità. Strategie di integrazione e inclusione per le disabilità e i Bisogni Educativi Speciali, Erickson, Trento.

lanes D., Cramerotti S. (2013). Alunni con Bisogni educativi speciali. Indicazioni operative per promuovere l'inclusione scolastica sulla base della DM del 27/12/2012 e della CM n.8 6/3/2013. Erickson: Trento.

lanes D., Cramerotti S., Capaldo N., Rondanini L. (2016). Insegnare domani nella scuola primaria. Erickson: Trento.

Johnson, D. \& Johnson, R. (1987). Learning together and alone. Upper Saddler River. N.J.: PrenticeHall.

Miato S.A. Miato L. (2003). La didattica inclusiva. Organizzare l'apprendimento cooperativo metacognitivo, Erikson.

Organizzazione Mondiale Della Sanità (OMS). (2007). ICF-CY. Classificazione Internazionale del Funzionamento, della Disabilità e della Salute. Versione per bambini e adolescenti, Erickson, Trento, p 212.

Pavone M. /2010). Dall'esclusione all'inclusione. Milano: Mondadori.

Polito M. (2000). Attivare le risorse del gruppo classe Nuove strategie per l'apprendimento reciproco e la crescita personale, Edizioni Erickson, Trento.

Rogers C.R. (1980). A Way of Being, Boston, Ma. Houghton Mifflin Co. (trad. it. Un modo di essere, Martinelli, Firenze, 1983).

Stueck, M. (2004). Stress management in Schools: an empirical investigation of a stress management system. Social Work Practitioner-Researcher, 16 (2).

Stueck, M. (2011). The concept of systemrelated stress reduction (SYSRED) in educational fields under the use of Biodanza. Problems of education in the 21st century,29.

Stuek M., Villegas A. (2012). Overview on Biodanza research - an 8-aspect-approach, Biopsychological Basics of Life, 1, pp. 4-13. < http://www.Biodanza.org/bionet.pdf >, ultima consultazione 05/09/2015. 
Toro Acuna G.C., Demelas L. (2013). IBF - International Biocentric Foundation - Rete CIMEB Rete Mondiale dei Centri di Investigazione delle Musiche e degli Esercizi di Biodanza $®$ "Biodanza e Neuroscienze" Dispensa Formazione Insegnanti Biodanza Sistema Rolando Toro, Editorial Eleusis, p.p. 11,12 .

Toro Araneda R. (2007/2013) Biodanza: musica, movimento, comunicazione espressiva per lo sviluppo armonico della personalità, Edizioni Red, Como.

Toro Araneda R. (2012). Teoria della Biodanza, raccolta dei testi a cura della A.L.A.B. (Associazione Latino-Americana di Biodanza), CIMEB testi, Volume I, Edizioni Nuova Prhomos, Perugia.

Visentin S. (2016). Facilitatori e barriere nella pratica sportiva di atleti con disabilità fisiche: un studio esplorativo. Journal of Special Education for Inclusion, 4 (1), pp. 121-135.

\section{(c)}

This work is licensed under a Attribution-NonCommercial-NoDerivatives 4.0 International (CC BY-NC-ND 4.0). 